\title{
32. LATE OLIGOCENE LARGER FORAMINIFERA FROM KOKO GUYOT, SITE 309
}

\author{
L. Hottinger, Geological and Paleontological Institute, University of Basel, Basel, Switzerland
}

\begin{abstract}
Based mainly on the presence of Spiroclypeus tidoenganensis Van der Vlerk, 1925, the latest Tertiary fauna on top of Köko Guyot is assigned to the late Oligocene. This was a time when coral reef sands were formed in water depths between 30 and 70 meters.
\end{abstract}

\section{INTRODUCTION}

The larger foraminifera from Kōko Guyot (DSDP Site 309), provided by H. P. Luterbacher, can be used to date and infer water depth of the youngest shallowwater sediments preserved on top of the volcanic edifice before its sinking to its present-day depth of 1454 meters.

The fauna has an additional paleobiogeographic interest which provides a supplementary mid-Pacific location of late Paleogene heterosteginids. A systematic revision of Pacific and Tethyan heterosteginid species in time and space is needed to clarify the paleogeographic and phylogenetic origin of the present-day $H$. depressa.

The material from Site 309 is moderately well preserved and has a chalky aspect. The foraminiferal shells are empty and their internal surfaces are coated with a thin, crystalline layer of secondary carbonate deposits. Perforation and layering of the chamber walls are mostly obscured by recrystallization. The best preparation method proved to be rather thick thin sections covered with Canada balsam.

\section{FAUNA}

Material from Sample 309-1, CC, yielded the following species.

\section{Spiroclypeus tidoenganensis Van der Vlerk, 1925}

(Figures 1, 2)

1925 Spiroclypeus tidoenganensis Van der Vlerk, p. 16; pl. 1, fig. 12; pl. 5 , fig. 42,47

1957 Spiroclypeus tidoenganensis Van der Vlerk, Hanzawa, p. 46; pl. 3 , fig. 1-6; pl. 4, fig. 1, 8-10.

1966 Spiroclypeus $\mathrm{cf}$ tidoenganensis Van der Vlerk, Hottinger, p. 65; pl. 15, fig. 12,13

Remarks: The generic identification is based on the structural elements of the test: The nummulitid canal system, the secondary subdivision of the chambers and the presence of lateral secondary chamberlets. The specific identification must be based mainly on the comparatively large proloculus in the megalospheric generation combined with the characteristics of the equatorial growth spiral. These specimens are intermediate between the late Eocene to early Oligocene species (Cole, 1957; Hottinger, 1964) and S. anghiarensis (Silvestri) of early Miocene age (Hottinger, 1966, pl. 15).

Heterostegina assilinoides Blanckenhorn emend. Henson, 1937 (Figure 3)

1937 Heterostegina assilinoides Blanckenhorn. Henson, p. 48; pl. 4, fig. 1-5; text-fig. 1, 2 .

1966 Grzybowskia assilinoides (Blanckenhorn). Hottinger, p. 65 ; pl.

15, fig. 1.

Remarks: The generic identification is based on the structural elements of the test: The nummulitic canal system, the secondary sub-

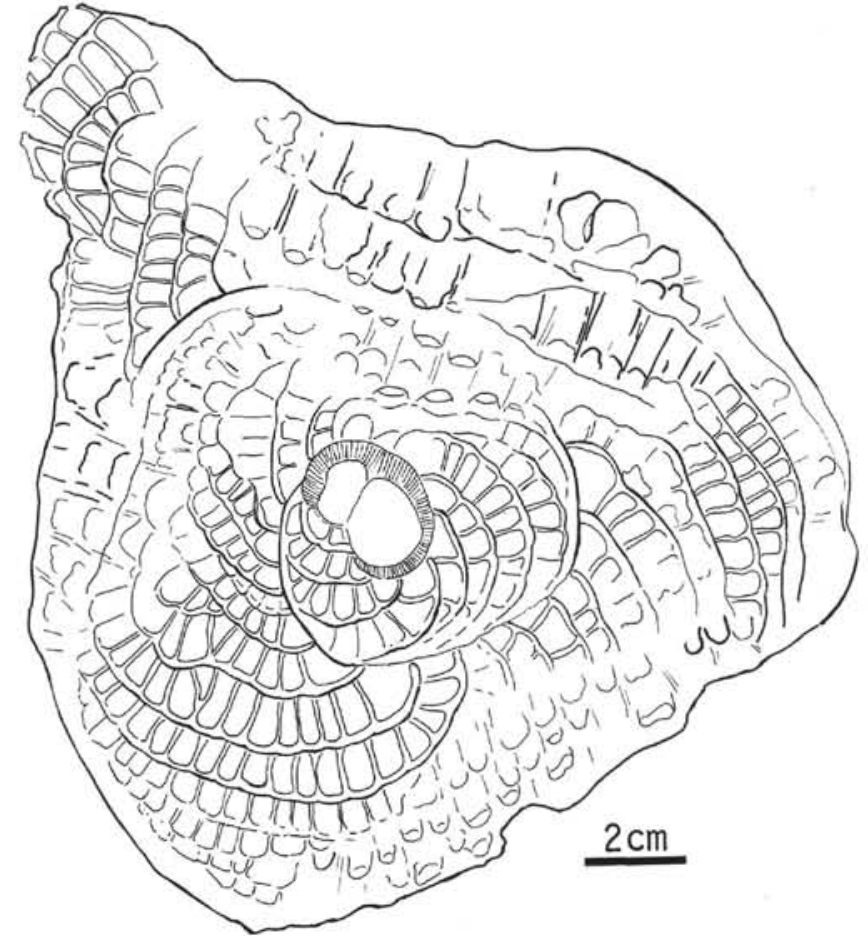

Figure 1. Spiroclypeus tidoenganensis Van der Vlerk. Equatorial section of megalospheric specimen, Kōko Guyot, late Oligocene.

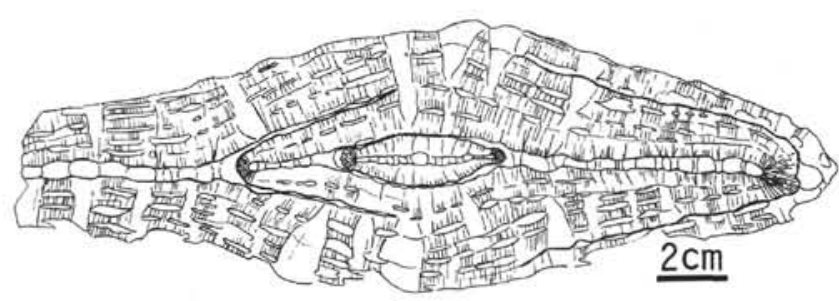

Figure 2. Spiroclypeus tidoenganensis Van der Vlerk. Transverse section of megalospheric, undulated specimen. Kōko Guyot, late Oligocene.

division of the chambers, and the absence of lateral secondary chamberlets. The reticulate ornamentation of the involute shell particular for one of several parallel phylogenetic lineages in Heterostegina occurs in the type species of the genus, $H$. depressa d'Orbigny, 1826, and in the type species of the genus Grzybowskia, G. multifida Bieda, 1950. Therefore, "Involute" species have to be kept in the genus Heterostegina s.str. Specific identification must be based on the 


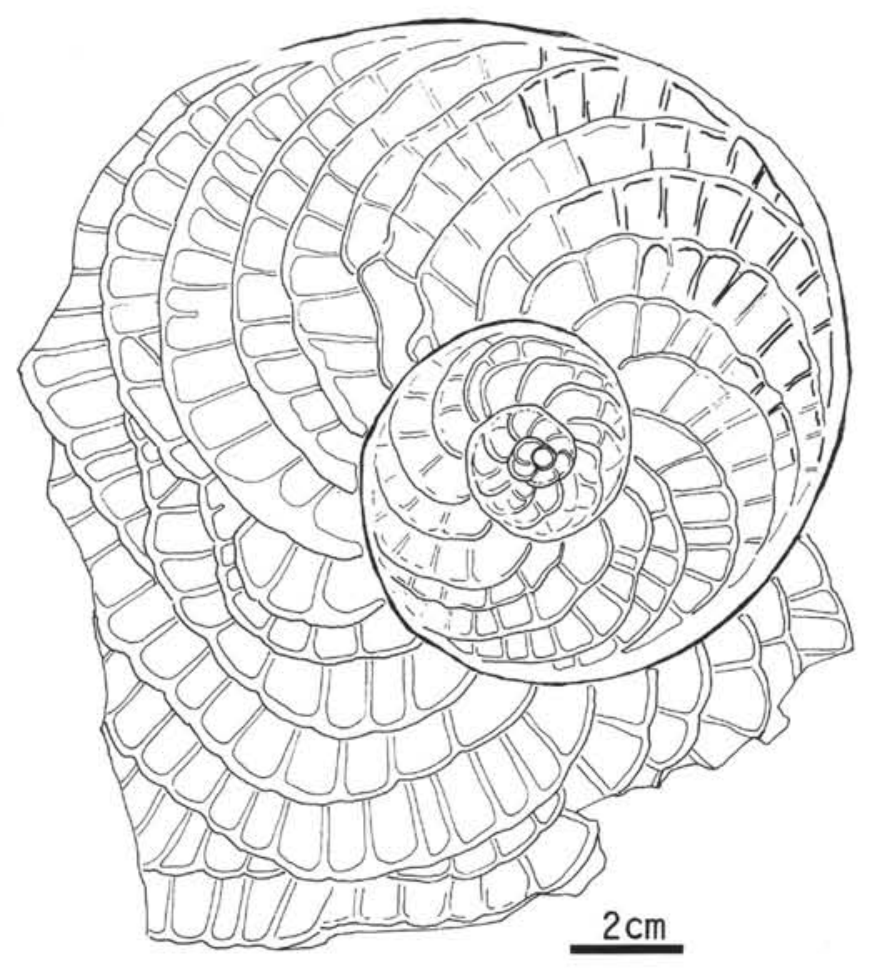

Figure 3. Heterostegina assilinoides Blanckenhorn s.l. Equatorial section of megalospheric specimen. Kōko Guyot, late Oligocene.

diameter of the proloculus in the megalospheric generation, on the characteristics of the growth spiral and on the size and the number of chamberlets in a given chamber. The specific determination proposed here must be provisional as long as the synonymy of Mediterranean, Indonesian, and Pacific species (Cole, 1954, 1957) are not clearly established.

\section{Amphistegina sp.}

Remarks: Numerous but poorly preserved specimens represent two small, almost lenticular species of this genus. Several names from the literature are available to designate the two species present. Since no precise stratigraphic or ecologic meaning can be attached to the available names, it is not worthwhile to determine the material to specific level. All fossil species of Amphistegina need a thorough revision.

\section{Sphaerogypsina sp.}

Remarks: This spherical acervulinid is characterized by the absence of a layer of main chambers. In the present state of knowledge, species names in this genus have no meaning at all.

\section{BIOSTRATIGRAPHIC INTERPRETATION}

Spiroclypeus tidoenganensis and Heterostegina assilinoides both occur together with Lepidocyclina praetournoueri in Morocco. S. tidoenganensis coexists with Miogypsina septentrionalis (late Oligocene), $H$. assilinoides with $M$. basraensis (early Miocene, compare Hottinger, 1966, table 16, and Drooger, 1966, ibid. table $10)$. The stratigraphic value of the species in Spiroclypeus is more precise than the one in heterosteginids for two reasons: at Site 309, many more specimens of $S$. tidoenganensis are available for study than specimens of $H$. assilinoides and there is much more variability in species of Heterostegina than in species of Spiroclypeus. Therefore, the biostratigraphic interpretation of the fauna from Site 309 is based on $S$. tidoenganensis. Its range covers approximately the late Oligocene. In the early Oligocene, Spiroclypeus is represented by the much smaller $S$. aff. carpathicus (Hottinger, 1964) whereas $S$. anghiarensis follows in the earliest Miocene (Aquitanian).

In the Pacific (Saipan), Hanzawa (1957) indicates a range for $S$. tidoenganensis corresponding to the Tagpochau limestone. Hanzawa (1957, p. 8) confuses the situation by stating that this limestone interfingers with Globigerina limestones containing Orbulina univer$s a$ and is consequently of middle Miocene age. This considerable difference in dating the range of $S$. tidoenganensis might be explained by some error of lithostratigraphic correlation in the field work on Saipan or to reworking of the larger foraminifera (see Hanzawa, 1957, pl. 32, fig. 1).

Presently, the species of Amphistegina and Sphaerogypsina have no biostratigraphic value.

\section{PALEOECOLOGIC INTERPRETATION}

The fauna from Site 309 can be compared best with Recent assemblages of larger foraminifera characterized by amphisteginids, heterosteginids, and sphaerogypsinids. Assemblages of this type occur in the Red Sea exclusively on hard substrate or on small patches of aerated coralline sand in between coral colonies. They are restricted to depths between 30 and 70 meters. The presence of coral fragments in the sample from Site 309 supports this interpretation.

\section{REFERENCES}

Cole, S. W., 1954. Larger foraminifera and smaller diagnostic foraminifera from Bikini drill holes: U.S. Geol. Surv. Prof. Paper 260-O, p. 569-608.

1957. Larger foraminifera from Eniwetok Atoll drill holes: U.S. Geol. Surv. Prof. Paper 260-V, p. 743.

Drooger, C. W., 1966. Miogypsinidae of Europe and North Africa: Sess. Comm. Medit. Neog. Stratigr. Proc. 3rd, 1964. Brill (Leiden), p. 51.

Hanzawa, S., 1957. Cenozoic foraminifera of Micronesia. Geol. Soc. Am., Mem. 66.

Henson, F. R. S., 1937. Larger foraminifera from Aintab, Turkish Syria: Eclog. Geol. Helv., v. 30, p. 45.

Hottinger, L., 1964. Les genres Operculina et Heterostegina (foraminiferes) et leur utilité stratigraphique: Mém. Bur. Rech. Géol. Min., v. 28, p. 1013.

1966. Heterostegina, Grzybowskia et Spiroclypeus néogènes du Maroc. Sess. Comm. Medit. Neog. Stratigr. Proc. 3rd, 1964. Brill (Leiden), p. 61.

Van der Vlerk, M., 1925. A study of Tertiary foraminifera from the "Tidoengsche Landen" (E Borneo): Nederl. Indie, Dienst Mijnb. Wetensch. Meded., v. 3, p. 13. 